\title{
Estrogenic Activity Profiles of River Water in Kobe, Japan Assessed by In Vitro Bioassay and Chemical Analysis
}

\author{
Takako YAMAGUCHI, Naoki INOUE, Hiroyasu YAMAZAKI \\ Department of Hygienic Chemistry, Faculty of Pharmaceutical Sciences, Kobe-Gakuin \\ University, 1-1-3 Minatojima, Chuo-ku, Kobe 650-8586, Japan
}

\begin{abstract}
In order to investigate the estrogenic activity profiles and quantitatively characterize the substances contributing to estrogenic activity in the river, biological and chemical analysis were applied to river water extracts. Water samples were collected throughout one year at upstream, midstream and downstream locations of the Akashi River system in Kobe, Japan. The highest estrogenic activity in river water was observed at site A-3 $\left(5.13 \times 10^{-12} \mathrm{M}\right.$ estradiol equivalent concentration (EEQ)) in Akashi River, which had inflow of discharge effluent from a sewage treatment plant (ESTP) immediately at the upper stream. Results of LC-MS analysis and E-screen assay from samples of A-3 and ESTP demonstrated that estrogens and estrogenic activities detected in site A-3 originated from ESTP. Of the three estrogens and six xenoestrogens analyzed in this study, di (2-ethylhexyl) phthalate (DEHP) and bisphenol A (BPA) were detected in almost all the samples but the calculated EEQ values from these xenoestrogens were below the detection limit of the bioassay. Estrone (E1) was found at sites A-2, A-3 and ESTP, while E2 was found at site A-3 and ESTP. These estrogens (E1 and E2) are the major substances contributing to the estrogenic activity of the samples. However, the EEQ values determined by E-screen assay were lower than those calculated from LC-MS analysis. In consideration of the former reports, the estrogenic activity of river water may be suppressed by estrogen antagonists. Furthermore, the estrogenic activity observed in site I-1 may be affected by some unknown chemicals in the effluent from landfill (EL).
\end{abstract}

Keywords: estradiol equivalent, estrogenic activity, landfill, river water, sewage treatment plant

\section{INTRODUCTION}

In recent years, endocrine disrupting compounds (EDCs) have been recognized as a new category of environmental contaminants that interfere with the functions of endocrine systems (Colborn and Clement, 1992; Kavlock et al., 1996). Endocrine disrupting compounds have adverse effects on wildlife and human health not only on an individual basis but also at the population and community levels (Colborn and Clement, 1992; Kavlock et al., 1996). Reports of feminized male fish (White et al., 1994; Sumpter 1995) and the abnormal sexual development of reptiles and birds (Guillete Jr. et al., 1994) have suggested that many chemicals, both natural and synthetic, exhibit estrogenic activity. The increased incidences of breast, testicular, and prostate cancer; reduced reproductive success; and immunological and neurological dysfunction have caused concern about the ubiquity of hormone-mimicking environmental pollutants. A wide variety of compounds, including polycyclic aromatic hydrocarbons, polychlorinated biphenyls, dioxins, pesticides, phthalate esters, alkylphenols, and endogenous or exogenous steroids are considered to be EDCs (Colborn et al., 1993; Jobling et al., 1995), and potential sources, such as industrial discharges, domestic discharges, and livestock waste, have been identified in field studies (Snyder et al., 1999; Tanghe et al., 1999; Solé et al., 2000; Tashiro et al., 2003). In this context, the

Address correspondence to Takako Yamaguchi, Department of Hygienic Chemistry, Faculty of Pharmaceutical Sciences, Kobe-Gakuin University, Email: yamaguti@pharm.kobegakuin.ac.jp Received November 25, 2011, Accepted June 14, 2012. 
EDCs flowing into our environment have become an important social issue so it is important to examine estrogenic activity in the aquatic environment. There are many reports about the occurrence and fate of EDCs and estrogenicity monitoring in the aquatic environment in Europe and the USA, but a few investigations on the levels and distribution of EDCs in Asian countries. In Japan, most drinking water is produced from surface water, so the removal of EDCs from surface water has become a research priority not only for environmental protection but more importantly for public health. Therefore, it is important to investigate the level and distribution of EDCs in surface water.

The objectives of this study are to investigate the estrogenic activity profiles and level of estrogenic compounds in river water by combined biological and chemical analysis. Screening using bioassay could provide an integral estrogenic activity of a sample, and could also help evaluate the estrogenic contributions by certain chemicals in combination with chemical analysis. Two rivers (Akashi River system) were chosen for investigation since some of the drinking water used in this area is produced from the river water, and they also receive effluent from a sewage treatment plant (ESTP) or effluent from landfill (EL). Water samples were collected throughout one year and the estrogenic activity and levels of estrogenic substances in these rivers were determined using E-screen assay and LC-MS analysis. Potential risks to aquatic organisms and public health were assessed based on the data obtained from the E-screen assay and LC-MS analysis.

\section{MATERIALS AND METHODS \\ Sampling}

River water was sampled at eight different sites along the Akashi River system (Fig. 1). The two rivers (Akashi River and I River) examined in this study flow through the western suburbs of Kobe and Akashi. Site A-1 (Fujiwara Bridge, N34 44' 23.55", E135 $5^{\circ} 34.84^{\prime \prime}$, was where Akashi River flows through a predominantly agricultural

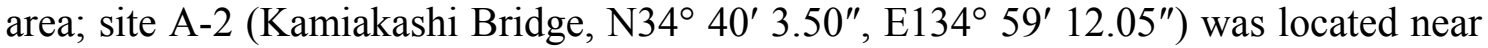
the sluice gate of the water supply for Akashi; and site A-3 (Kaei Bridge, N34 $39^{\prime}$ 35.62", E134 ${ }^{\circ} 59^{\prime}$ 4.36") received ESTP. Site I-1 (Gomigataira Bridge, N34 ${ }^{\circ} 41^{\prime}$ 50.59", E135 $5^{\prime}$ 34.84") in I River received EL, and I-2 (Jyonan Bridge, N34 40' 17.09", E135 $0^{\circ}$ '54.96") was located downstream of I River. Samples of river water were taken once a month from June 2005 to May 2006. All samples were collected in light-shielded glass bottles and brought to the laboratory.
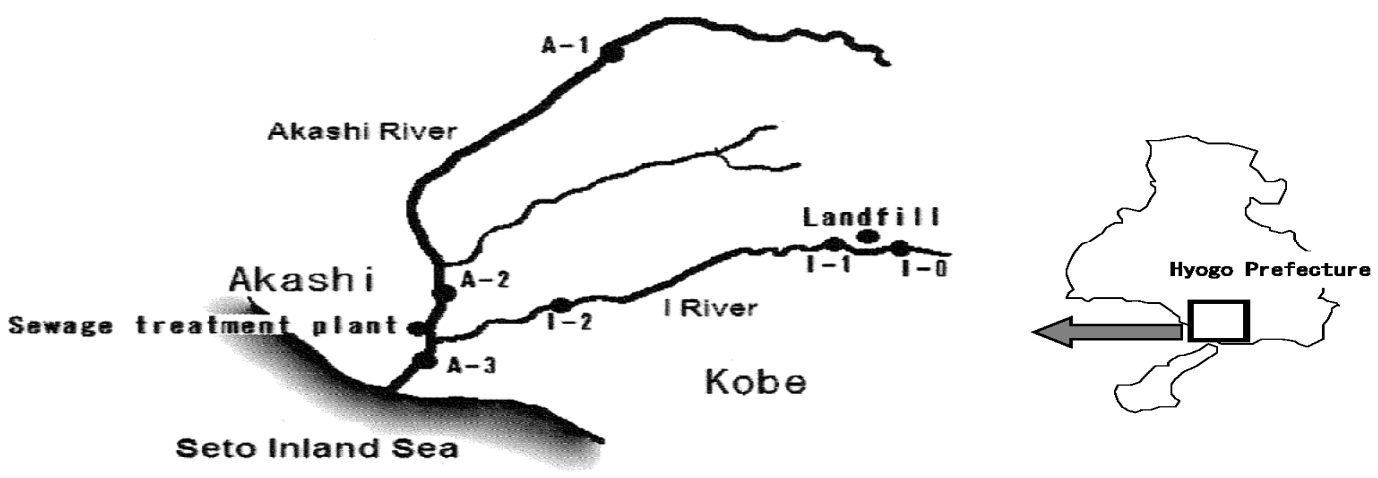

Fig. 1 - Location of the sampling sites along the Akashi River system. 
The samples were stored at $4^{\circ} \mathrm{C}$ and extracted within $24 \mathrm{~h}$. Samples of ESTP, EL and water from the upper reach of I-1 (I-0, N34 $41^{\prime} 52.97^{\prime \prime}$, E135 $\left.5^{\circ} 5^{\prime} 6.94^{\prime \prime}\right)$ were also collected in September 2006. All samples were collected the day when it did not rain for the past three or more days.

\section{Extraction}

Prior to extraction, duplicate water samples (1L each) were spiked with the surrogate standards: 50 ng each of BPA- $d_{16}$, E2- $d_{4}$, (Cambridge Isotope Laboratories, Inc., USA) and DEHP- $d_{4}$ (Wako Pure Chemical Industries Ltd., Japan) for chemical analysis, while another unspiked duplicated water samples were used for the bioassay. The water samples had their $\mathrm{pH}$ adjusted to 2.5 with concentrated sulfuric acid and were then filtered through a Millex AP filter unit (pore size $2.0 \mu \mathrm{m}$; Millipore Corp., USA) and subjected to solid-phase extraction (SPE) at a flow of $10 \mathrm{~mL} / \mathrm{min}$ on ODS cartridge (Sep-pak Plus C18, Waters, USA) preconditioned with $5 \mathrm{~mL}$ of acetone, $10 \mathrm{~mL}$ of methanol, and $5 \mathrm{~mL}$ of ultrapure water $(\mathrm{pH} 2)$. The cartridge was washed with $6 \mathrm{~mL}$ of ultrapure water $(\mathrm{pH} 2)$ and eluted with $5 \mathrm{~mL}$ of acetone. The eluates were evaporated under a gentle nitrogen stream. Shortly before the samples were dried, $50 \mu \mathrm{L}$ DMSO was added to each of the samples for bioassay, and the remaining acetone was further evaporated. The extracted samples were stored in sealed vials at $-20^{\circ} \mathrm{C}$ until they were used.

\section{E-screen assay}

The estrogen receptor-positive human MCF-7 breast cancer cell line was obtained from Dainippon Sumitomo Pharma Co., Ltd. (Japan). The MCF-7 cells were routinely grown in Dulbecco's modified Eagle's medium (DMEM, Gibco, Life Technologies Corp., USA) supplemented with $15 \mathrm{mg} / \mathrm{L}$ phenol red, 10\% fetal bovine serum (FBS), $2 \mathrm{mM}$ L-glutamine (Gibco, Life Technologies Corp., USA), and 1\% non-essential amino acid solution (Gibco, Life Technologies Corp., USA) at $37^{\circ} \mathrm{C}$ in an atmosphere of $5 \% \mathrm{CO}_{2}$ and $95 \%$ air under saturated humidity. A stock solution of $1 \mathrm{mM} 17 \beta$-estradiol (E2) was prepared with ethanol. Unless otherwise specified, all chemicals were purchased from Sigma-Aldrich Corp. (USA). The FBS was treated with charcoal-dextran (CD) to remove all steroids according to the protocol of Stanley et al. (1977).

The E-screen assay was carried out according to the method of Korner et al. (2001). Subconfluent MCF-7 cells were trypsinized, and resuspended in steroid-free experimental medium. The experimental medium consisted of phenol red-free DMEM supplemented with 5\% CD-FBS, $10 \mathrm{mM}$ HEPES, $2 \mathrm{mM}$ L-glutamine, and 1\% non-essential amino acid solution. The cells were seeded into 24-well plates at a density of 10,000 cells/well and allowed to attach for $24 \mathrm{~h}$. After $24 \mathrm{~h}$ (day 1), the medium was replaced with the experimental medium, which contained one of five different dilutions of the river water extract. The extracted samples were diluted 40 to 1,000 -fold $(0.2$ to 5 L final volume) with steroid-free experimental medium. Each dilution was tested in four replications per assay. Eight wells per assay without hormones were used as negative controls, and five wells with E2 concentrations ranging from $10^{-12} \mathrm{M}$ to $10^{-8} \mathrm{M}$ were used as positive controls in each assay. Five days later (day 6), the assay was terminated during the late exponential phase of proliferation, and cell number was assessed using the sulforhodamine assay (Skehan et al., 1990). In this assay, the extinction of sulforhodamine B (SRB) at $550 \mathrm{~nm}$ is directly proportional to the cell number. 


\section{Evaluation of the E-screen assay}

The primary endpoint of the E-screen assay is the number of cells relative to that in the hormone-free control. The proliferative effect (PE) of a sample is then calculated as the ratio between the highest cell number found in the sample and the cell number of the negative control (Schiliró et al., 2004):

$$
\mathrm{PE}=\text { max cell number }{ }_{\text {sample }} / \text { cell number } \text { negative control }
$$

The estrogenic activity of each sample was then evaluated by determining its relative efficacy using the relative proliferative effect (RPE). The RPE compares the maximum proliferation induced by a sample with that induced by E2. Thus, full agonists (RPE = $100 \%)$ can be distinguished from partial agonists (RPE $<100 \%)$ :

$$
\mathrm{RPE} \%=\left(\mathrm{PE}-1_{\text {sample }} / \mathrm{PE}-1_{\mathrm{E} 2}\right) \times 100
$$

The estrogenic activities of the river water samples were quantitatively evaluated via the determination of the estradiol equivalent concentration (EEQ), which represents the total amount of estrogenic compounds in the river water sample normalized to the E2 concentration. Estradiol equivalent concentration was calculated from the cell proliferation dose-response curves produced in the presence of E2 $\left(10^{-12} \mathrm{M}\right.$ to $\left.10^{-8} \mathrm{M}\right)$ and the sample.

The relative potency of xenoestrogen is evaluated by the estradiol equivalency factor (EEF). The EEF is the quotient of the $\mathrm{EC}_{50}$ value of $\mathrm{E} 2$ and the test compound. The $\mathrm{EC}_{50}$ value for the E-screen assay is the concentration at which $50 \%$ of $\mathrm{PE}$ is achieved. The proliferative effect and $\mathrm{EC}_{50}$ values of xenoestrogens were calculated from dose-response curves $\left(10^{-10} \mathrm{M}\right.$ to $\left.10^{-5} \mathrm{M}\right)$. The estradiol equivalency factor values derived from E-screen assay were 1, 0.02, $4 \times 10^{-5}$ and $2 \times 10^{-6}$ for E2, E1, BPA and DEHP, respectively.

\section{LC-MS/MS analysis}

One of the products of solid-phase extraction eluted with $5 \mathrm{~mL}$ of acetone was evaporated under a gentle nitrogen stream and then the residue was extracted with ultrapure water $(1 \mathrm{~mL})$ and ethylacetate $(3 \mathrm{~mL})$. The ethylacetate phase was evaporated under nitrogen, and the residue was cleaned using an $\mathrm{NH}_{2}$ cartridge (Sep-pak Plus $\mathrm{NH}_{2}$, Waters, USA) that had been activated with $5 \mathrm{~mL}$ of methanol and $10 \mathrm{~mL}$ of ethylacetate. Estrogens were eluted with $6 \mathrm{~mL}$ of methanol, before the methanol was evaporated to $1 \mathrm{~mL}$, and quantification was carried out by LC-MS. Other eluents of the solid-phase extraction products used for the xenoestrogen analysis were evaporated under a gentle nitrogen stream, and the residue was precleaned by column chromatography (Berkner et al., 2004). In order to separate the non-polar substances from the analytes, a 3 g Wakogel C-200 column (75 $150 \mu \mathrm{m}$, Wako Pure Chemical Industries Ltd., Japan) conditioned with hexane was used. To remove the non-polar compounds from the column, it was eluted with 30 $\mathrm{mL}$ hexane, before elution with $70 \mathrm{~mL}$ of hexane:ethylacetate $(9: 1 \mathrm{v}: \mathrm{v})$ and a third fraction was produced using $40 \mathrm{~mL}$ of hexane:ethylacetate $(3: 7 \mathrm{v}: \mathrm{v})$. Both fractions were evaporated until dryness under a gentle nitrogen stream, and the residues were dissolved in $1 \mathrm{~mL}$ methanol prior to the xenoestrogen analysis. 
Liquid chromatographic analysis was performed on a Waters Alliance 2695 HPLC system (Waters, USA) equipped with a C18 reverse-phase column (Cadenza CD-18; $2.0 \mathrm{~mm}$ ID $\times 100 \mathrm{~mm} ; 3 \mu \mathrm{m}$; Imtakt, Japan). The column oven temperature was set to $20^{\circ} \mathrm{C}$, and the injection volume was $10 \mu \mathrm{L}$. Chromatography for estrone (E1), $17 \beta$-estradiol (E2), and estriol (E3) were carried out using the mobile phase A (methanol) : B (acetonitrile) : $\mathrm{C}$ (water) $=25: 30: 45$. On the other hand, a mobile phase of A (methanol) : B (water) $=90: 10$ was used for the xenoestrogens. The flow rate of the mobile phase was $0.2 \mathrm{~mL} / \mathrm{min}$. An electrospray (ESI) triple quadruple Quattro Ultima mass spectrometer (Waters, USA) was operated in negative and positive ionization modes, and acquisition was achieved in multiple reactions monitoring (MRM) or selected ion monitoring (SIM) mode. The instrument control and data acquisition were performed using the MassLynx ${ }^{\mathrm{TM}}$ V4.0 software. The conditions for each compound are presented in Table 1.

\section{Quality assurance and quality control}

In order to identify the efficiency and reproducibility of the analytical procedure, spiked river water sample was analyzed. The average recoveries of the compounds are shown in Table 2. The recoveries of estrogens and xenoestrogens through this extraction procedure ranged from $81.0 \%$ to $102.2 \%$ except for those for 4-nitrophenol (PNP) (28\%) and 3-methyl-4-nitrophenol (PNMC) (46.3\%). In addition, E2- $d_{4}, \mathrm{BPA}-d_{16}$ and DEHP- $d_{4}$ as surrogate standards were added to all the samples at a spiked concentration of $50 \mathrm{ng} / \mathrm{L}$ to monitor the procedural performance and matrix effects, and their recoveries were $95.6 \pm 12.7 \%, 84.3 \pm 9.8 \%$ and $87.3 \pm 8.7 \%$, respectively.

The reported estrogens and xenoestrogens concentrations were corrected by the surrogate recoveries. Procedural blank was analyzed with the water samples and only trace amount of the DEHP (less than the limit of detection (LOD)) was detected in procedural blanks, so no blank correction was necessary. The LOD of the target compounds were determined based on the ratio of signal to noise $(S / N=3)$. The LOD for E1, E2, E3, BPA, DEHP, NP, OP, PNP and PNMC were 0.1, 0.2, 0.2, 5, 5, 5, 1, 0.5 and $0.5 \mathrm{ng} / \mathrm{L}$, respectively.

Table 1 - ESI-MS conditions for each of the investigated compounds.

\begin{tabular}{|c|c|c|c|c|c|}
\hline \multirow[t]{2}{*}{ Compound } & \multirow[t]{2}{*}{ Ion mode } & \multicolumn{2}{|c|}{ Monitoring ion (m/z) } & \multirow[t]{2}{*}{ Cone (v) } & \multirow[t]{2}{*}{ Collision (v) } \\
\hline & & SIM & MRM & & \\
\hline Estrone ( E1) & - & 269 & 145 & 65 & 30 \\
\hline $17 \beta$-estradiol ( E2) & - & 271 & 145 & 65 & 30 \\
\hline Estriol ( E3) & - & 287 & 145 & 65 & 30 \\
\hline $17 \beta$-estradiol- $d_{4}\left(\mathrm{E} 2-d_{4}\right)$ & - & 275 & 145 & 45 & 30 \\
\hline Bisphenol A ( BPA) & - & 227 & - & 45 & - \\
\hline Di ( 2-ethylhexyl ) phthalate ( DEHP) & + & 391 & - & 20 & - \\
\hline Nonylphenol ( NP) & - & 219 & - & 60 & - \\
\hline Octylphenol ( OP ) & - & 205 & - & 55 & - \\
\hline 4-Nitrophenol ( PNP) & - & 138 & - & 45 & - \\
\hline 3-Methyl-4-Nitrophenol ( PNMC ) & - & 153 & - & 39 & - \\
\hline Bisphenol A- $d_{16}\left(\mathrm{BPA}-d_{16}\right)$ & - & 243 & - & 65 & - \\
\hline Di ( 2-ethylhexyl) phthalate- $d_{4}$ ( DEHP- $d_{4}$ ) & + & 395 & - & 20 & - \\
\hline
\end{tabular}


Table 2 - Recovery of estrogens and xenoestrogens from the river water samples.

\begin{tabular}{cccc}
\hline Compound & Spiked $(\mathrm{ng} / \mathrm{L})$ & Recovery $(\%)$ & S.D. \\
\hline E1 & 50 & 89.1 & 4.2 \\
E2 & 50 & 102.2 & 10.9 \\
E3 & 50 & 95.0 & 3.8 \\
BPA & 50 & 94.7 & 8.2 \\
DEHP & 50 & 86.9 & 1.4 \\
NP & 50 & 81.0 & 6.3 \\
OP & 50 & 89.3 & 7.8 \\
PNP & 50 & 28.0 & 11.7 \\
PNMC & 50 & 46.3 & 14.1 \\
\hline
\end{tabular}

Note: $(n=3)$

\section{RESULTS AND DISCUSSION \\ Estrogenic activity of river water samples}

The results of the E-screen assay of the river water extracts are shown in Fig. 2. The annual mean values of PE, RPE, and EEQ are summarized in Table 3.

Estrogenic activity was observed in river water extracts from all sampling sites, and these activities were slightly higher in Akashi River than in I River. The estrogenic activities showed monthly variations, but not so large. Seasonal variations of estrogenic activity in surface water related with biodegradation of estrogen were reported (Matsuoka et al., 2005; Motegi and Nagata, 2007; Wang et al., 2011). From these reports, it appeared that the decline in estrogenic activity observed in summer, except at site A-3, was due to the biodegradation of estrogen.

The site with the maximum estrogenic activities were A-3 (annual average : $5.13 \times 10^{-12}$ EEQ) in Akashi River (Table 3, Fig. 2). The site A-3 immediately receives discharge effluent from a STP in the upper stream, and in ESTP, estrogens have been identified as the major compounds responsible for estrogenic activity (Desbrow et al., 1998; Johnson and Sumpter, 2001; Furuichi et al., 2004; Ying et al., 2009). The increase of estrogenic activity in August at site A-3 may be due to the increase in the ratio of discharge effluent from STP to river water in dry season. In I River, weak estrogenic activities were found in site I-1 and I-2. Though site I-1 was located upstream, the samples of I-1 showed slightly higher estrogenic activity than I-2. It appears that the estrogenic activity detected at A-3 was caused by estrogens from the STP. In addition, I-1 receives effluent from a landfill, so the estrogenic activity detected at this site may be caused by the effluent from the landfill. Therefore, samples of ESTP, EL and upper reach of I-1 (I-0) were also examined. The highest estrogenic activity was observed in ESTP $\left(9.54 \times 10^{-12}\right.$ $M$ EEQ) followed by that in site A-3 $\left(5.78 \times 10^{-12} \mathrm{M}\right.$ EEQ) as shown in Table 4 . This result indicates that ESTP was responsible for the estrogenic activity of site A-3. On the other hand, the EEQ in site I-0 was below the detection limit. The slightly increased estrogenic activity was observed in EL and I-1, and the activity was higher in EL than in I-1 (Table 4). From these results, it appears that the activity of site I-1 was influenced by EL. 
Table 3 - Annual mean of estrogenic activity in the river water extracts.

\begin{tabular}{cccc}
\hline Sample & PE & RPE $(\%)$ & EEQ $(M)$ \\
\hline A-1 & $1.29 \pm 0.19$ & $11.53 \pm 1.90$ & $1.26 \times 10^{-12}$ \\
A-2 & $1.45 \pm 0.27$ & $13.09 \pm 2.63$ & $2.01 \times 10^{-12}$ \\
A-3 & $1.76 \pm 0.16$ & $19.47 \pm 1.81$ & $5.13 \times 10^{-12}$ \\
I-1 & $1.31 \pm 0.17$ & $12.24 \pm 3.86$ & $1.28 \times 10^{-12}$ \\
I-2 & $1.19 \pm 0.23$ & $10.08 \pm 4.19$ & $1.16 \times 10^{-12}$ \\
$\mathrm{E} 2\left(10^{-10} \mathrm{M}\right)$ & $4.23 \pm 0.12$ & 100 & \\
\hline
\end{tabular}

Note: Values represent mean \pm S.D. $(n=12)$

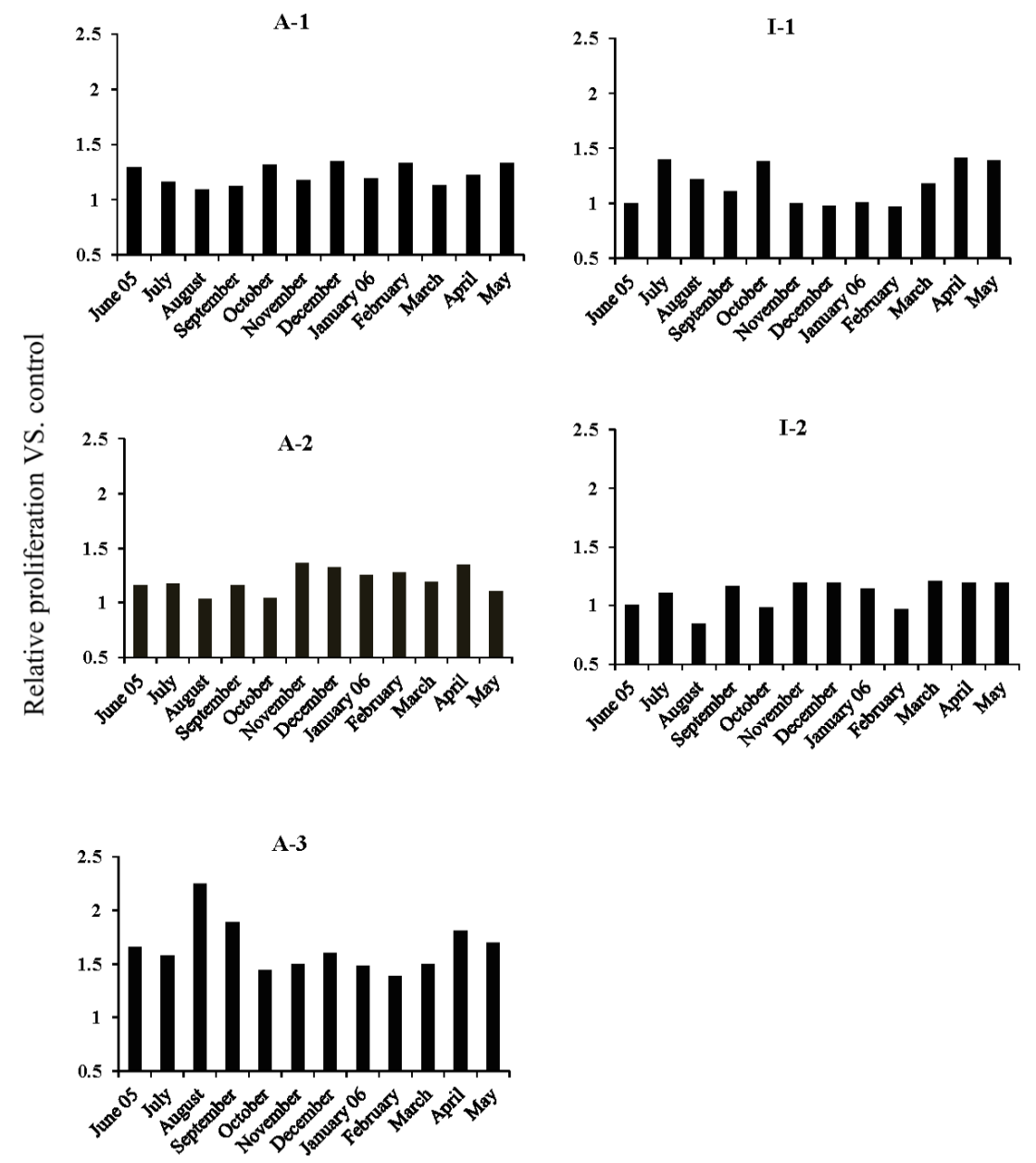

Fig. 2 - Annual variations of estrogenic activity of the river water extracts by E-screen assay. 


\section{Comparison of the E2 equivalents derived from the E-screen assay and LC-MS analysis}

The results of our analysis of estrogenic compounds and EEQ estimated by the E-screen assay in the Akashi River system are shown in Table 4. The annual concentrations (range, mean) in June 2005 to May 2006 and September 2006 are also presented. Of the three estrogens and six xenoestrogens examined in this study, only analytes with concentrations above the LOD at one or more sampling sites are shown in Table 4.

Estron and E2 were found in the samples from A-3 (annual mean: E1; $18.3 \mathrm{ng} / \mathrm{L}, \mathrm{E} 2$; $2.4 \mathrm{ng} / \mathrm{L})$, and the samples from ESTP (E1; $46.9 \mathrm{ng} / \mathrm{L}, \mathrm{E} 2 ; 11.1 \mathrm{ng} / \mathrm{L})$ and A-3 (E1; 9.2 $\mathrm{ng} / \mathrm{L}, \mathrm{E} 2 ; 3.2 \mathrm{ng} / \mathrm{L})$ in September 2006. In addition, BPA and DEHP were found in almost all samples in Akashi River. Estradiol and ethynylestradiol (EE2) are the major substances contributing to estrogenic activity in surface water (Körner et al., 2001; Snyder et al., 2001). Estradiol is transformed into E1 in activated sludge from STP. Estradiol-glucuronides, metabolites of natural estrogens, are transformed to E2 and then immediately converted to E1 (Ternes et al., 1999). Results of LC-MS analysis and E-screen assay demonstrated that estrogens and estrogenic activities detected at site A-3 originated from STP effluent. The values of EEQ calculated from LC-MS analysis for site A-3 (annual mean), ESTP, and site A-3 (September 2006) were $1.02 \times 10^{-11} \mathrm{M}, 4.43$ $\times 10^{-11} \mathrm{M}$, and $1.25 \times 10^{-11} \mathrm{M}$, respectively . On the other hand, the EEQ obtained from the bioassay for site A-3 (annual mean), ESTP, and site A-3 (September 2006) were 5.13 $\times 10^{-12} \mathrm{M}, 9.54 \times 10^{-12} \mathrm{M}$, and $5.78 \times 10^{-12} \mathrm{M}$, respectively. In the present study, the EEQ obtained from the bioassay were not consistent with those obtained from the chemical analysis. The EEQ values determined by E-screen assay were lower than those calculated from LC-MS analysis. This result was consistent with the results of previous

Table 4 - Comparison of the estradiol equivalent concentrations determined in the E-screen assav with LC-MS analvsis.

\begin{tabular}{|c|c|c|c|c|c|c|c|}
\hline \multirow[t]{2}{*}{ Sample } & \multirow[t]{2}{*}{ Site } & \multicolumn{5}{|l|}{ LC/MS } & \multirow{2}{*}{$\frac{\text { E-SCREEN }}{\text { EEQ (M) }}$} \\
\hline & & $\overline{E 1(n g / L)}$ & $\mathrm{E} 2(\mathrm{ng} / \mathrm{L})$ & $\mathrm{BPA}(\mathrm{ng} / \mathrm{L})$ & $\operatorname{DEHP}(\mathrm{ng} / \mathrm{L})$ & $\overline{\operatorname{EEQ}(\mathrm{M})}$ & \\
\hline \multirow[t]{2}{*}{$\begin{array}{r}\text { Jun. } 2005- \\
\text { May } 2006\end{array}$} & A-1 & $<$ LOD & $<$ LOD & $\begin{array}{c}<\text { LOD - } 11.9 \\
6.5\end{array}$ & $\begin{array}{c}51-335 \\
210\end{array}$ & - & $1.26 \times 10^{-12}$ \\
\hline & A-2 & $<\mathrm{LOD}$ & $<\mathrm{LOD}$ & $\begin{array}{c}<\text { LOD }-27.6 \\
20.3\end{array}$ & $\begin{array}{c}68-483 \\
320\end{array}$ & - & $2.01 \times 10^{-12}$ \\
\hline \multirow[t]{3}{*}{$\begin{array}{l}\text { Range } \\
\text { Mean }\end{array}$} & $A-3$ & $\begin{array}{c}7.2-25.8 \\
18.3\end{array}$ & $\begin{array}{c}1.1-4.9 \\
2.4\end{array}$ & $\begin{array}{c}18.4-36.7 \\
30.1\end{array}$ & $\begin{array}{c}77-501 \\
390\end{array}$ & $1.02 \times 10^{-11}$ & $5.13 \times 10^{-12}$ \\
\hline & $\mathrm{I}-1$ & $<$ LOD & $<\mathrm{LOD}$ & $\begin{array}{c}19.1-47.3 \\
39.7\end{array}$ & $\begin{array}{c}216-1435 \\
1090\end{array}$ & - & $1.28 \times 10^{-12}$ \\
\hline & $\mathrm{I}-2$ & $<\mathrm{LOD}$ & $<\mathrm{LOD}$ & $\begin{array}{c}<\text { LOD }-24.5 \\
21.8\end{array}$ & $\begin{array}{c}103-826 \\
580\end{array}$ & - & $1.16 \times 10^{-12}$ \\
\hline \multirow[t]{8}{*}{ Sep. 2006} & A-1 & $<$ LOD & $<\mathrm{LOD}$ & 10.1 & 180 & - & $1.87 \times 10^{-12}$ \\
\hline & $A-2$ & $<\mathrm{LOD}$ & $<\mathrm{LOD}$ & 25.4 & 240 & - & $1.66 \times 10^{-12}$ \\
\hline & ESTP & 46.9 & 11.1 & 38.6 & 480 & $4.43 \times 10^{-11}$ & $9.54 \times 10^{-12}$ \\
\hline & $A-3$ & 9.2 & 3.2 & 31.3 & 280 & $1.25 \times 10^{-11}$ & $5.78 \times 10^{-12}$ \\
\hline & $\mathrm{I}-0$ & $<\mathrm{LOD}$ & $<\mathrm{LOD}$ & $<$ LOD & 100 & - & - \\
\hline & EL & $<\mathrm{LOD}$ & $<\mathrm{LOD}$ & 51.6 & 2470 & - & $1.78 \times 10^{-12}$ \\
\hline & $\mathrm{I}-1$ & $<$ LOD & $<\mathrm{LOD}$ & 44.2 & 1310 & - & $1.39 \times 10^{-12}$ \\
\hline & $\mathrm{I}-2$ & $<\mathrm{LOD}$ & $<\mathrm{LOD}$ & 23.1 & 760 & - & $1.21 \times 10^{-12}$ \\
\hline
\end{tabular}

Notes: Only analytes with concentrations $>$ LOD at one or more sampling sites are shown. LOD : limit of detection, - : not detected 
reports (Wang et al., 2011) and this can be explained by the presence of unknown antagonists in the water sample (Tanaka et al., 2001, Witters et al., 2001). Antiestrogenic activity of river water and sediment in South Korea and USA were also reported (Seung-Min et al., 2006; Sellin et al., 2010; Sellin et al., 2011). Furthermore, it has been reported that dibenzyl phthalate (DBzP), mono-n-butyl phthalate (MBP), and mono -2-ethylhexyl phthalate (MEHP), which are the biodegraded intermediates of di-n-butyl phthalate (DBP) and DEHP and are widely used in large quantities as plasticizers, show estrogen antagonist activity (Okubo et al., 2003; Ohtani et al., 2005; Zang et al., 2011). These monoester phthalates were detected in river water in Japan, and the detected concentration of MBP and MEHP were $0.03-0.58 \mu \mathrm{g} / \mathrm{L}$ and $0.06-2.2$ $\mu \mathrm{g} / \mathrm{L}$, respectively. The detected highest concentration of MEHP $(2.2 \mu \mathrm{g} / \mathrm{L})$ was expected to cause a $50 \%$ decrease in the agonist activity of $10^{-9} \mathrm{M}$ E2 in the yeast two-hybrid assay (Ohtani et al., 2004). Although the analysis of MEHP was not performed in this study, the concentration of DEHP and MEHP in river water were found to be approximately in the same level in Japan (Ohtani et al., 2005). We also confirmed that the concentration level of DEHP in the Akashi River system is consistent with former reports (Hashizume et al., 2002; Suzuki et al., 2002; Ohtani et al., 2005). In addition, DEHP and DBP were degraded to MEHP and MBP for about 70 and 100\%, respectively, in river water (Hashizume et al., 2002). These results imply that MEHP, in the Akashi River system may have a similar level of concentration as those of other rivers in Japan and may lead to contribute to some estrogen antagonist activities.

For I River samples, estrogens were not found. Di (2-ethylhexyl) phthalate was detected in all samples and was detected in higher concentrations for samples from EL $(2,470$ $\mathrm{ng} / \mathrm{L})$ and I-1 (1,310 ng/L). Bisphenol A was detected in both rivers; but site I-0 was below the LOD (Table 4). From these results, it appeared that the concentration of xenoestrogens detected in this study contributed a little but the increased estrogenic activity observed in site I-1 might have been affected by some unknown chemicals in EL (Soto et al., 2004; Sarmah et al., 2006; Vigano et al., 2008).

\section{Risk assesment}

A number of studies have reported on the endocrine disrupting effects of EDCs on aquatic organisms. The observed lowest concentration reported to have an effect for estrogenic responses in medaka, trout and roach was $10 \mathrm{ng} / \mathrm{L}$ for E1 and E2 (Routledge et al., 1998; Metcalfe et al., 2001). Moreover, very low concentration of E2 at $1 \mathrm{ng} / \mathrm{L}$ led to the induction of vitellogenin in male trout (Sumpter and Johnson, 2005). After male fathead minnow was exposed to $\mathrm{E} 1$ at $31.8 \mathrm{ng} / \mathrm{L}$, a significant increase in plasma vitellogenin level was observed (Panter et al., 1998). Bisphenol A at 22.4 and $2.24 \mu \mathrm{g} / \mathrm{L}$ significantly enhanced the numbers of female amphibians with sex ratios of $70 \%$ and $65 \%$, respectively, as compared with the control tests with the sex ratio of $50 \%$ (Levy et al., 2004). In this study, the mean concentrations (site A-3) of BPA, E1 and E2 are 0.03 $\mu \mathrm{g} / \mathrm{L}, 18.3 \mathrm{ng} / \mathrm{L}$ and $2.4 \mathrm{ng} / \mathrm{L}$, respectively. Bisphenol $\mathrm{A}$ is two orders of magnitudes lower than the effective concentration and close to those noted for E2. However, the concentrations of E1 and E2 described above are for site A-3 which receives ESTP, upper reach sites are at levels way below the effective concentration. 


\section{CONCLUSION}

In this study, we investigated the estrogenic activity profiles of river water in Kobe, Japan by combined biological and chemical analysis. The highest estrogenic activity in river water was observed at site A-3 in Akashi River and site A-3 received discharge effluent from STP. Results of LC-MS analysis and E-screen assay from samples of A-3 and ESTP demonstrated that estrogens and estrogenic activities detected in site A-3 originated from STP effluent. No amount of estrogen was detected in I-1 but the estrogenic activity might have been affected by some unknown chemicals in EL.

Of the three estrogens and six xenoestrogens analyzed in this study, DEHP and BPA were detected in almost all the samples but the calculated EEQ values from these xenoestrogens were below the detection limit of the bioassay. Estrone was found at sites A-2, A-3 and ESTP, and E2 was found at site A-3 and ESTP. These estrogens (E1 and E2) are the major substances contributing to the estrogenic activity of the samples. However, the EEQ values determined by E-screen assay were lower than those calculated from LC-MS analysis. This may be due to the presence of unknown estrogen antagonists such as MEHP in the river water. To clarify the difference of EEQ between E-screen assay and LC-MS analysis, further investigation of estrogen antagonists is required. Since some of the drinking water used in this area is produced from surface water and because river water contains a complex mixture of substances that display endocrine disrupting activity, further investigation of continuous ingestion of these substances in very small quantities is required on behalf of human and aquatic organisms' health.

\section{REFERENCES}

Berkner S., Streck G. and Herrmann R. (2004) Development and validation of a mehod for determination of trace levels of alkylphenols and bisphenol $\mathrm{A}$ in atmospheric samples. Chemosphere, 54(4), 575-584.

Colborn T. and Clement C. (1992) Chemically induced alteration in sexual development: the wildlife/human connection, p.403, Princeton Scientific Publishing Company, NJ, USA.

Colborn T., Vom Saal F. S. and Soto A. M. (1993) Developmental effects of endocrine-disrupting chemicals in wildlife and humans. Environ. Health Perspect., 101(5), 378-384.

Desbrow C., Routledge E. J., Brighty G. C., Sumpter J. P. and Waldock M. (1998) Identification of estrogenic chemicals in STW effluent. 1. Chemical fractionation and in vitro biological screening. Environ. Sci. Technol., 32(11), 1549-1558.

Furuichi T., Kannan K., Giesy J. P. and Masunaga S. (2004) Contribution of known endocrine disrupting substances to the estrogenic activity in Tama River water samples from Japan using instrumental analysis and in vitro reporter gene assay. Water Res., 38(20), 4491-4501.

Guillete Jr. L. J., Gross T. S., Masson G. R., Matter J. M., Percival H. F. and Woodward A. R. (1994) Developmental abnormalities of the gonad and abnormal sex hormone concentrations in juvenile alligators from contaminated and control lakes in Florida. Environ. Health Perspect., 102(8), 680-688. 
Hashizume K., Nanya J., Toda C., Yasui T., Nagano H. and Kojima N. (2002) Phthalate esters detected in various water samples and biodegradation of phthalates by microbes isolated from river water. Biol. Pharm. Bull., 25(2), 209-214.

Jobling S., Reynolds T., White R., Parker M. G. and Sumpter J. P. (1995) A variety of environmentally persistent chemicals including some phthalate plasticizers are weakly estrogenic. Environ. Health Perspect., 103(6), 582-587.

Johnson A. C. and Sumpter J. P. (2001) Critical review removal of endocrine-disrupting chemicals in activated sludge treatment works. Environ. Sci. Technol., 35(24), 4697-4703.

Kavlock R. J., Daston G. P., DeRosa C., Fenner-Crisp P., Gray L. E., Kaattari S., Lucier G., Luster M., Mac M. J., Maczka C., Miller R., Moore J., Rolland R., Scott G., Sheehan D. M., Sinks T. and Tilson H. A. (1996) Research needs for the risk assessment of health and environmental effects of endocrine disruptors: a report of the U. S. EPA-sponsored workshop. Environ. Health Perspect., 104 (Suppl 4), 715-740.

Körner W., Spengler P., Bolz U., Schuller W., Hanf V. and Metzger J. (2001) Substances with estrogenic activity in effluents of sewage treatment plants in southwestern Germany. 2. Biological analysis. Environ. Toxicol. Chem., 20(10), 2142-2151.

Matsuoka S., Kikuchi M., Kimura S., Kurokawa Y. and Kawai S. (2005) Determination of estrogenic substances in the water of Muko river using in vitro assays, and the degradation of natural estrogens by aquatic bacteria. J. Health Sci., 51(2), 178-184.

Metcalfe C. D., Metcalfe T. L., Kiparissis Y., Koenig B. G., Khan C., Hughes R. J., Croley T. R., March R. E. and Potter T. (2001) Estrogenic potency of chemicals detected in sewage treatment plant effluents as determined by in vivo assays with Japanese medaka (Oryzias latipes). Environ. Toxicol. Chem., 20(2), 297-308.

Motegi C. and Nagata T. (2007) Enhancement of viral production by addition of nitrogen plus carbon in subtropical surface waters of the South Pacific. Aquat. Microb. Ecol., 48(1), 27-34.

Ohtani Y., Shimada Y. and Kozawa K. (2004) Concentration and estrogen-antagonist activity of phthalic acid mono-ester in the river water. Annual report of Gunma prefectural institute of public health and environmental sciences, 36, 34-38.

Ohtani Y., Shimada Y., Shiraishi F. and Kozawa K. (2005) Estrogen-antagonist activities of phthalic acid mono-n-butyl ester and phthalic acid mono-2-ethyhexyl ester. Environ. Sci., 12(4), 207-212.

Okubo T., Suzuki T., Yokoyama Y., Kano K. and Kano I. (2003) Estimation of estrogenic and anti-estrogenic activities of some phtthalate diesters and monoesters by MCF-7 cell proliferation assay in vitro. Biol. Pharm. Bull., 26(8), 1219-1224.

Panter G. H., Thompson R. S. and Sumpter J. P. (1998) Adverse reproductive effects in male fathead minnows (Peepholes promelas) exposed to environmentally relevant concentrations of the natural estrogens, estradiol and estrone. Aquatic Toxicol., 42(4), 243-253.

Routledge E. J., Sheahan D., Desbrow C., Brighty G. D., Waldock M. and Sumpter J. P. (1998) Identification of Estrogenic Chemicals in STW Effluent. 2. In Vivo Responses in Trout and Roach. Environ. Sci. Technol., 32(11), 1559-1565.

Sarmah A. K., Northcott G. L. and Leusch F. D. L. (2006) A survey of endocrine disrupting chemicals (EDCs) in municipal sewage and animal waste effluents in the Waikato region of New Zealand. Sci. Total Environ., 355(1-3), 135-144. 
Schiliró T., Pignata C., Fea E. and Gill G. (2004) Toxicity and estrogenic activity of a wastewater treatment plant in northern Italy. Arch. Environ. Contam. Toxicol., 47(4), 456-462.

Sellin M. K., Snow D. D. and Kolok A. S. (2010) Reductions in hepatic viterogenin and estrogen receptor alpha expression by sediments from an agriculturally impacted waterway. Aquat. Toxicol., 96(2), 103-108.

Sellin M. K., Conoan N. H., Cox M. B., Sangster J. L., Baslsiger H. A., Bridges A. A., Cowman T., Knight L. A., Bartelt-Hunt S. L. and Kolok A. S. (2011) The anti-estrogenic activity of sediments from agriculturally intense watersheds: assessment using in vivo and in vitro assays. Aquat. Toxicol., 105, 189-198.

Seung-Min O., Kwangsik P. and Kyu-Hyuck C. (2006) Combination of in vitro bioassays encompassing different mechanisms to determine the endocrine-disrupting effects of river water. Sci. Total Environ., 354, 252-264.

Skehan P., Streng R., Scudiero D., Monks A., McMahon J., Vistica D., Warren J. T., Bokesch H., Kenney S. and Boyd M. R. (1990) New colorimetric cytotoxicity assay for anticancer-drug screening. J. Natl. Cancer Inst., 82, 1107-1112.

Snyder S. A., Keith T. L., Verbrugge D. A., Synder E. M., Gross T. S., Kannan K. and Giesy J. P. (1999) Analytical Methods for Detection of Selected Estrogenic Compounds in Aqueous Mixtures. Environ. Sci. Technol, 33, 2814-2820.

Snyder S. A., Villeneuve D. L., Snyder E. M. and Giesy J. P. (2001) Identification and quantification of estrogen receptor agonists in wastewater effluents. Environ. Sci.Technol., 35, 3620-3625.

Solé M., López de Aldalda M. J., Castillio M., Porte C., Ladegaard-Pedersen K. and Barcelo D. (2000) Estrogenicity Determination in Sewage Treatment Plants and Surface Waters from the Catalonian Area (NE Spain). Environ. Sci. Technol, 34, 5076-5083.

Soto A. M., Calabro J. M., Prechtl N. V., Yau A. Y., Orlando E. F., Daxenberger A., Kolok Jr. A. S., Guillette L. J., Bizec B. L., Lange I. G. and Sonnenschein C. (2004) Androgenic and estrogenic activity in water bodies receiving cattle feedlot effluent in Eastern Nebraska, USA. Environ. Health Perspect., 112, 346-352.

Stanley E. R., Palmer R. E. and Sohn U. (1977) Development of methods for the quantitative in vitro analysis of androgen-dependent and autonomous Shionogi carcinoma 115 cells. Cell, 10, 35-44.

Sumpter J. P. (1995) Feminized responses in fish to environmental estrogens. Toxicol. Lett., 82-83, 737-742.

Sumpter J. P. and Johnson A. C. (2005) Lessons from endocrine disruption and their application to other issue concerning trace organic in the aquatic environment. Environ. Sci. Technol., 39, 4321-4332.

Suzuki T., Yaguchi K., Igarashi T., Inaba M., Usami M. and Yasuda K. (2002) Monitoring of endocrine disrupting chemicals in well water for drinking and the Tama river in the Tama region of Tokyo. Ann. Rep. Tokyo Metr. Res. Lab. P.H., 53, 238-243.

Tanaka H., Yakou Y., Takahashi A., Higashitani T. and Komori K. (2001) Comparison between estrogenicities estimated from DNA recombinant yeast assay and from chemical analyses of endocrine disruptors during sewage treatment. Water Sci. Technol., 43, 125-132.

Tanghe T., Devriese G. and Verstraete W. (1999) Nonylphenol and estrogenic activity in aquatic environmental samples. J. Environ. Qual., 28, 702-709. 
Tashiro Y., Takemura A., Fujii H., Takahira K. and Nakanishi Y. (2003) Livestock wastes as a source of estrogens and their effects on wildlife of Manko tidal flat, Okinawa. Mar. Pollut. Bull., 47, 143-147.

Ternes T. A., Kreckel R. and Mueller J. (1999) Behavior and occurrence of estrogens in municipal sewage treatment plants - II. Aerobic batch experiments with activated sludge. Sci. Total. Environ., 225, 91-99.

Vigano L., Benfenati E., Gauwenberge A. V., Eidem J. K., Erratico C., Goksoyr A., Kloas W., Maggioni S., Mandich A. and Urbatzka R. (2008) Estrogenicity profile and estrogenic compounds determined in river sediments by chemical analysis, ELISA and yeast assays. Chemosphere, 73, 1078-1089.

Wang L., Ying G., Zhao J., Liu S., Yang B., Zhou L., Tao R. and Su H. (2011) Assessing estrogenic activity in surface water and sediment of Liao River system in northeast China using combined chemical and biological tools. Environ. Pollut. Total. Environ., 159, 148-156.

White R., Jobling S., Hoare S. A., Sumpter J. P. and Parker M. G. (1994) Environmentally persistent alkylphenolic compounds are estrogenic. Endcrinology, 135, 175-182.

Witters H. E., Vangenechten C. and Berckmans P. (2001) Detection of estrogenic activity in Flemish surface waters using an in vitro recombinant assay with yeast cells. Water Sci. Technol., 43, 117-123.

Ying G. G., Kookana R. S., Kumar A. and Mortimer M. (2009) Occurrence and implications of estrogens and xenoestrogens in sewage effluents and receiving waters from South East Queensland. Sci. Total Environ., 407, 5147-5155.

Zang Z., Hu Y., Zhao L., Li J., Zhu D. and Hu J. (2011) Estrogen agonist/antagonist properties of dibenzyl phtalate (DBzP) based on in vitro and in vivo assays. Toxicol. Lett., 207, 7-11. 